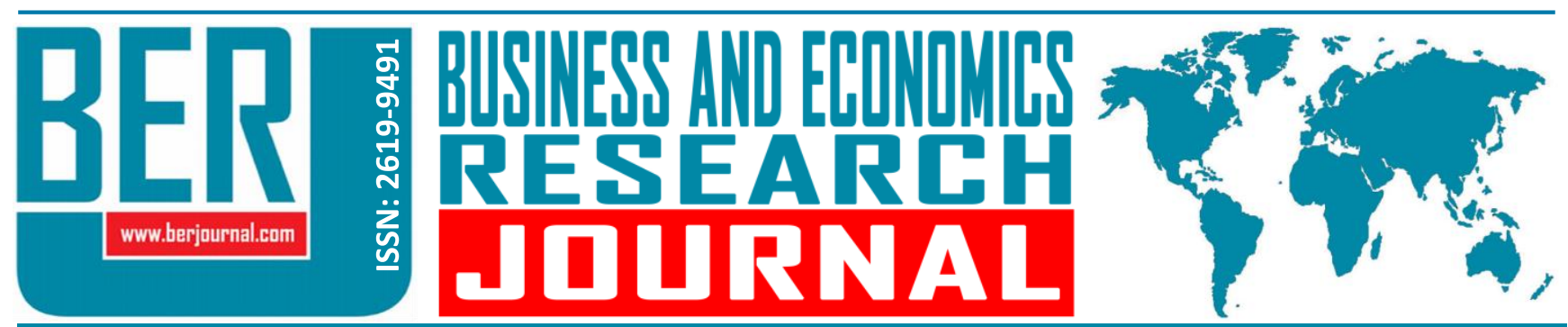

Business and Economics Research Journal Vol. 9, No. 3, 2018, pp. 559-578 doi: 10.20409/berj.2018.123

\section{Hisse Senedi Seçim Kararı Vermede Etkili Olan Bireysel Yatırımcı Davranışları: BIST Örneği}

\section{Duygu Arslanturk Collu ${ }^{a}$}

Öz: Bu çalışma Borsa İstanbul'da işlem yapan bireysel yatırımcıların hisse senedi seçim kararı verirken önemli gördükleri temel faktörleri belirlemek amacıyla yapılmıştır. Bu amacı gerçekleştirmek üzere bütünleşik bir DEMATEL ve ANP yönteminin kullanıldığı çalışmada, verilerin toplanması 5'li Likert ölçeğine uygun bir anketin hazırlanması ile sağlanmıştır. Toplamda 21 alt faktörün yer aldığı anket; muhasebe verileri, tavsiyeler, kişisel finansal ihtiyaçlar, firmaya özgü bilgiler ve diğer faktörler olmak üzere 5 ana gruba ayrılmıştır. Çalışma sonuçları, Borsa istanbul'da işlem yapan bireysel hisse senedi yatırımcıları için önem sıralamasına göre; aracı kurum tavsiyesi, yüksek getiri için risk almaya istekli olmak, hızlıca zengin olmak, arkadaş ve aile tavsiyesi, hissedarların çoğunluğunun fikirleri ve çeşitlendirme ihtiyacı şeklinde sıralanan 6 faktörün oldukça önemli olduğunu ortaya koymuştur. Diğer taraftan şirket performansının tüm piyasa performansına duyarlılığı, büyük piyasaların endekslerinde yaşanan dalgalanma ve gelişmeler ile hisse senetlerinin uygun fiyatı olması şeklindeki 3 faktörün ise yatırımcılar tarafından en az önem verilen faktörler olduğu tespit edilmiştir.

\section{Invidual Investors' Behaviour on Stock Selection Decision: A Case of BIST}

Abstract: The study seeks to determine the main factors influencing stock selection decisions of individual investors in Borsa istanbul (BIST). To achieve this objective, an integrated Decision Making Trial and Evaluation Laboratory (DEMATEL) and Analytic Network Process (ANP) method was used and a five-point Likert scale survey questionnaire was designed. The questionnaire included twenty one factors that belong to five categories, namely, accounting information; recommendations; personal financial needs, firm specific attributes and other factors. The results show that there are six most important factors affecting the stock selection decisions of individual investors at the BIST which are brokerage house recommendations, willingness of taking risk for high returns, get rich quick, opinions of the firm's majority stockholders, suggestions from friends and family and diversification needs. On the other hand, three factors were found to be the least influencing factors on individual investors' stock selection decisions. The least influencing factors in order of importance were sensitivity of firm performance to overall market performance, fluctuations/developments in the indices of the major markets, affordable share price.
Anahtar Sözcükler: Hisse Senedi Seçim Kararı, Bireysel Yatırımcı, DEMATEL, ANP, BIST

JEL: G11, G41, C39

$\begin{array}{ll}\text { Geliş } & : \text { 30 Mart 2018 } \\ \text { Düzeltme } & : \text { 25 Mayıs 2018 } \\ \text { Kabul } & : \text { 02 Temmuz 2018 } \\ \text { Tür } & : \text { Araştırma }\end{array}$

Keywords: Stock Selection Decision, Invidual Investor, DEMATEL, ANP, BIST

JEL: G11, G41, C39
Received : 30 March 2018

Revised : 25 May 2018

Accepted : 02 July 2018

Type : Research 


\section{Giriş}

18. yüzyılın ortaları, geleneksel iktisat teorilerinin başlangıç noktası olarak kabul edilmektedir. Bu dönemde ortaya çıkarılan teoriler arasında en önemli görüleni ise beklenen fayda teorisi olmuştur. Aslında bir iktisat modeli olan beklenen fayda teorisi aynı zamanda geleneksel finans teorilerinin temelini oluşturmaktadır. Fayda olarak bir mal ya da hizmet tüketiminden bireylerin sağladıkları tatminin ölçüsünün kullanıldığı bu teori, belirsizlik şartları altında karar veren bireyin yatırım alternatifleri arasından kendisi için en faydalı olanını tercih edeceğini kabul etmektedir. Bu modele göre, bireyler sadece akıllarını kullanmakta ve her türlü duygusallıktan ve dış etkiden uzak durmaya çalışmaktadırlar (Kapoor ve Prosad, 2017:51; Gümüş vd., 2013:73). 1844 yılında Mill tarafından ortaya atılan ekonomik insan (homo economicus) modeli ise, benzer olarak bireylerin tatminini maksimum seviyeye çıkarmaya çalıştıklarını ve bu süreçte rasyonel davranışlar sergilediklerini öne sürmüştür. Bu modelin üç temel varsayımı; mükemmel rasyonellik, mükemmel kişisel çıkar ve mükemmel bilgiden oluşmaktadır. Bu varsayımlar modern portföy teorisi, sermaye varlıklarını fiyatlandırma modeli ve etkin piyasalar hipotezi gibi geleneksel finansal modellerin temelini oluşturmuştur (Kapoor ve Prosad, 2017:51). Söz konusu geleneksel finans teorileri, yatırımcıların karar verirken rasyonel davrandıklarını ve belirli bir risk (getiri) seviyesinde en yüksek getiriye (en düşük riske) sahip alternatifi seçeceklerini kabul etmektedir. Ancak yapılan araştırmalar, yatırımcıların rasyonel olarak getirilerini maksimize etmek, portföylerini çeşitlendirmek ve riskten kaçınmak istemelerine rağmen bunu gerçek hayatta yaptıkları yatırımlarında gerçekleştiremediklerini ortaya koymuştur (Döm, 2003:14). Dolayısıyla, yatırımcıların finansal modellerin varsaydığı akılcı davranış beklentisinden önemli ölçüde sapmalar gösterdikleri söylenebilmektedir (Barberis ve Thaler, 2003: 1053).

Geleneksel finans teorilerinin aksine, yapılan çalışmalarda yatırımcıların karar alırken risk ve getiri dışında başka değişkenleri de dikkate aldıkları konusunda bulgulara ulaşılmıştır. Böylece gerçek hayatta yatırımcıların karar verirken kendilerine sadece ekonomik veya finansal göstergeleri rehber edinmedikleri, aynı zamanda kendi iç dünyaları, geçmiş deneyimleri ve olaylara bakış açılarının da aldıkları kararlarda etkili olduğu tespit edilmiştir (Yörükoğlu, 2007:24).

Tüm bu sonuçlar, geleneksel finans teorileri konusunda yeni bir tartışma başlatmış ve bu teorilerin piyasadaki olağandışı fiyat hareketleri ve getirileri açıklamada başarısız olduğunu ortaya koymuştur. Bu durum, geleneksel finans teorilerinin açıklayamadığı durumları yatırımcı psikolojisi ile ilişkilendiren davranışsal finans teorisinin gündeme gelmesini sağlamıştır (Estrada, 2001:6).

Davranışsal finans teorisinin temelleri, bireylerin karar alırken rasyonellikten sapabileceği konusunda psikolojik çalışmalar yapan Tversky ve Kahneman (1979)'ın ortaya attıkları beklenti teorisi ile atılmıştır. Beklenti teorisi, yatırımcıların psikolojik davranışlarını araştırmakta ve belirsizlik altında karar alma süreciyle ilgilenmektedir. Bireylerin riskten kaçınma eğilimlerinin kazanma isteklerine üstün geldiğini iddia eden bu teori, ruh halinin insan davranışlarını etkilemesi nedeniyle her zaman rasyonel davranışlar sergilenemediğini öne sürmektedir (Aydın ve Ağan, 2016:96). Dolayısıyla davranışsal finansta, insanların rasyonel davranışlar sergileyememesinin temel gerekçesi olarak, bilişsel kusurlar gösterilmiştir. Bu bilişsel kusurlar ya da psikolojik önyargılar sonucunda, bireysel yatırımcılar kazanan hisseleri olması gerekenden daha erken elden çıkarırken, kaybeden hisseleri ise çok uzun süre elde tutmakta, sürü davranışı göstermekte, kendilerine olan aşırı güvenlerinin sonucu olarak çok sık ve zararına işlem yapmakta, aşina oldukları hisselere duygusal olarak bağlanmakta, aşırı ve düşük reaksiyon göstermekte, kendi doğrularını destekleyici bilgiyi arama ve diğer bilgileri reddetme eğiliminde olmaktadırlar. Bir başka deyişle; yatırım kararları rasyonel kararlar olmaktan çıkmakta, bunun yerine daha çok kişinin sezgi ve hislerine dayalı olarak alınmaktadır (Döm, 2003: 14). Dolayısıyla alınan kararların, faydayı maksimize eden değil, karar alıcının en çok tatmin olduğu kararlar olduğunu söylemek mümkündür (Estrada, 2001:6).

Yatırımcıların alım satım davranışlarında rasyonellikten sapması, borsalarda dalgalanmalara neden olmakta ve böylece finansal piyasalar oldukça hareketli ve hisse fiyatları ise her gün değişir hale gelmektedir (Farooq vd. 2015: 63). İnsanların duygularını yatıım kararlarına yansıtmasının borsada felaketlere neden olabileceği gerçeğinden hareketle, hangi faktörlerin karar alma sürecini etkilediğinin tespit edilmesi piyasanın istikrarı için oldukça önemlidir (Kapoor ve Prosad, 2017). Ayrıca yatırımcılar, şirketler ve hükümetler gibi 
finansal planlamacıların gelecek ile ilgili kararlar verebilmeleri ya da düzenlemeler yapabilmeleri için bireylerin yatırım davranışlarını etkileyen faktörlerin belirlenmesi gerekmektedir. Bu kapsamda, yatıım kararlarını kendi veren yatıımcıların gelecekle ilgili finansal planlamalarını yapabilmeleri ve şirketlerin kendi yatırımcılarının tutumlarından yola çıkarak gelecekteki politikalarını ve stratejilerini oluşturabilmesi adına yatırım kararları üzerinde en etkili faktör veya faktörlerin belirlenmesi önem arz etmektedir. Ayrıca hükümetlerin yatırımcıların isteklerini karşılamak ve piyasa etkinliğine destek olabilmek amacıyla gereken ilave prosedürler ile gerekli yasal düzenlemeleri yapmasını sağlamak amacıyla da yatırım kararları üzerinde en etkili faktör veya faktörlerin belirlenmesi oldukça önemlidir (Al-Tamimi, 2006: 4). Söz konusu tarafların finansal planlamalarını yaparken, yatırımcıların algılarını etkileyen faktörlerin neler olduğunu bilmeleri, bu faktörleri kontrol ederek uygun kararlar verebilmelerini sağlayacaktır (Hossain ve Nasrin, 2012: 111).

Bu çalışmanın temel amacı bireysel yatırımcıların hisse senedi seçim sürecini etkileyen faktörleri belirlemektir. Bu doğrultuda literatürde yapılan çalışmalar hisse senedi seçim sürecinde yatırımcı davranışlarını etkileyen çok sayıda faktör olduğuna işaret etmektedir. Dolayısıyla yatııımcıların karar verme sürecinde başarılı olmalarının, seçim yaparken birçok faktörün dikkate alınmasına bağıı olduğunu söylemek mümkündür. Bu durumda hangi hisse senedinin seçileceği konusu birçok ana ve alt faktörün dikkate alınmasını gerektiren çok kriterli bir karar verme problemi olarak değerlendirilebilir. Konuya ilişkin yapılan çalışmaların büyük çoğunluğu faktörler arasındaki karşılıklı bağımlııkları ve geribildirim etkilerini dikkate almaksızın, her bir faktörün hisse senedi yatırımları üzerindeki tek yönlü etkisini araştırmıştır. Dolayısıyla faktörler arasındaki bu kantitatif bağımlılıklar üzerine analiz yapılamadığından önceki çalışmalarda bu faktörlerin ekonomik önemleri hakkında doğrudan değerlendirmeler veya doğru karşılaştırmalar yapmak mümkün olmamaktadır (Lee vd. 2011: 8375). Bu nedenle, bu çalışmada Borsa İstanbul'da işlem yapan bireysel yatırımcıların, hisse senedi alım-satımı yaparken hangi faktörleri dikkate aldıklarını belirlemek üzere çok kriterli karar verme yöntemlerinden DEMATEL (The Decision Making Trial and Evaluation Laboratory) ve ANP (Analytic Network Process ) yaklaşımları birlikte kullanıımıştır.

Literatürde konuya ilişkin çok sayıda çalışma yapılmış olmasına rağmen çalışmaların büyük çoğunluğunda anket yöntemi kullanılmış ve yatırımcı davranışlarını etkileyen faktörler olarak birbirinden farklı grup değişkenler ele alınmıştır. Bu çalışmada ise, anket yönteminden farklı olarak DEMATEL-ANP yöntemi kullanılmış ve kriterler arasındaki karşılıklı ilişkilerin dikkate alınması ve en yüksek/düşük öneme sahip kriterlerin belirlenmesi sağlanmıştır. Ayrıca, yatırımcıların kararlarını etkileyen tüm olası faktörlerin zaman içinde değiştiği ve farklı ülke özellikleri nedeniyle ülkeden ülkeye çeşitlilik gösterdiği fikrinden hareketle, mevcut çalışmanın uygulanan ülke, dönem ve yöntem konusunda literatüre katkı sağlaması ve piyasada istikrarı sağlamak üzere uygun ve etkili kararlar verebilmelerinde yatırımcılara, aracı kurumlara, şirketlere ve hükümete yeni bir bakış açısı sunması planlanmıştır.

Hisse senedi seçim sürecinde yatırımcı kararlarını etkileyen faktörlerin tespit edilmesinin amaçlandığı bu çalışma kapsamında öncelikle konuyla ilgili çalışmaların incelendiği literatür araştırmasına yer verilmiştir. Ardından kullanılan yöntem hakkında bilgi verilmiştir. Son bölümde ise, araştırma bulguları ortaya konularak sonuç ve değerlendirme kısmı oluşturulmuştur.

\section{Literatür Araştırması}

Hisse senedi seçim sürecinde yatırımcı kararlarını etkileyen faktörlerin belirlenmesi üzerine literatürde çok sayıda çalışma yapılmıştır. Bu çalışmalar kendi hesabına hisse senedi alım-satımı yapan bireysel yatırımcıların davranışlarının firmayla, makro çevreyle ve yatırımcının psikolojisiyle ilgili birçok içsel ve dışsal faktörden etkilendiklerini ortaya koymuştur (Gunathilaka, 2014: 108; Isidore ve Christie, 2015: 71). Öyle ki konuya ilişkin çalışmaların bir kısmı temsil etme, çıpalama, kumarcı yanılgısı ve mevcudiyet yanlılığı gibi davranışsal ön yargıları içeren içsel faktörleri araştırırken diğer bir kısmı ise muhasebe bilgileri, firma imajı, tavsiyeler, klasik servet maksimizasyonu faktörleri, nötr bilgiler, kişisel finansal ihtiyaçlar gibi dışsal faktörleri araştırmıştır (Isidore ve Christie, 2015: 71). Mevcut çalışmada dışsal faktörlere yoğunlaşımış ve dolayısıyla dışsal faktörlere ilişkin literatüre yer verilmiştir. Bu kapsamda Nagy ve Obenberger (1994), bireysel yatırımcı davranışlarını etkileyen faktörleri araştıran ilk çalışmalardan birisini gerçekleştirmişlerdir. Çalışmalarında, 34 alt kriteri kapsayan muhasebe bilgileri, nötr bilgiler, destekleyici tavsiyeleri, kişisel finansal 
ihtiyaçlar, firmanın imajı, sosyal bağlantı ve klasik servet maksimizasyonu olmak üzere yedi ana faktör kullanmışlardır. 137 yatırımcıya uygulanan anket sonucunda frekans dağılımlarına göre yatırımcıların hisse senedi seçerken farklı kriterleri kullanmalarına karşın, klasik servet maksimizasyonun (beklenen kazanç, çeşitlendirme ihtiyacı ve riskin minimize edilmesi) yatırımcılar için en önemli kriter olduğu sonucuna ulaşılmıştır.

Nagy ve Obenberger (1994)'in öncü niteliğindeki çalışması daha sonraki çalışmalara kaynaklık etmiş ve kullanılan faktörler diğer ülkelerde de test edilmiştir. Benzer bir çalışma, Yunan yatırımcıların hisse senedi alım satım davranışlarını araştıran Merikas vd. (2004) tarafından gerçekleştirilmiştir. 26 faktörün kullanıldığı çalışmada, 150 yatırımcıya anket uygulanmış ve yapılan faktör analizi sonucunda muhasebe bilgileri, nötr bilgiler, öznel/kişisel faktörler, destekleyici tavsiyeleri ve kişisel finansal ihtiyaçlar şeklinde beş ana faktör grubu oluşturulmuştur. Bulgular, Atina borsasında işlem yapan bireysel yatıımcı davranışlarını en çok muhasebe bilgilerinin (kurumsal kazanç, mali tabloların durumu ve firmanın endüstrideki durumu) etkilediğini göstermiştir. Ayrıca hızlıca zengin olmak alt kriterinin en yüksek ağırlığa sahip olduğu öznel/kişisel ana faktörünün, ikinci en önemli faktör grubu olduğu ortaya koyulmuştur.

Yatırımcı davranışları üzerinde en yüksek etkiye sahip ana faktörün muhasebe bilgileri olduğunu ileri süren bir diğer çalışma Al-Tamimi (2006) tarafından Birleşik Arap Emirlikleri (BAE)'nde gerçekleştirilmiştir. Söz konusu çalışmada firmanın imajı, muhasebe bilgileri, nötr bilgiler, destekleyici tavsiyeleri ve kişisel finansal intiyaçlar şeklindeki beş ana başlık altında 34 faktör dikkate alınmış ve 343 adet bireysel yatırımcıya anket uygulanmıştır. Araştırma sonucunda frekans dağııımlarına göre sırasıyla; beklenen kazanç, hızlıca zengin olmak, hisse senedinin satılabilirliği, firma hisselerinin geçmiş performansları yatırımcı davranışlarını etkileyen en önemli alt kriterler olarak öne çıkmıştır. Al-Tamimi (2006)'nın anket formunu modifiye ederek Nijerya'ya uygulayan Obamuyi (2013), bir firmanın hisse senetlerinin geçmiş performansı, beklenen sermaye artışı, kar dağıtım politikası, beklenen kazancı ve hızlıca zengin olmanın yatırımcıların en çok etkilendikleri faktörler olduğunu tespit etmiştir.

Hossain ve Nasrin (2012), Bangladeş piyasasında bireysel yatırımcıların hisse senedi seçimine etki eden temel faktörleri belirlemeye çalışmışlardır. 351 bireysel yatırımcıya anket anket uygulanarak 30 faktörün yatırımcı kararları üzerindeki etkisi araştırılmıştır. Faktör analizi, t-testi ve ANOVA testleri sonucunda bulgular firmanın itibarının, net aktif değerinin ve muhasebe verilerinin en çok dikkate alınan faktörler olduğunu ortaya koymuştur.

Yatırımcı davranışlarını Hindistan'ın farklı piyasaları için inceleyen Bennet ve diğerleri (2011), Das (2012), Velumoni ve Rau (2015) Hintli yatırımcılar için muhasebe bilgilerinin en önemli faktör olduğu konusunda benzer sonuçlara ulaşmışlardır. Tamil Nadu bölgesindeki yatırımcı davranışlarını araştıran Bennet ve diğerleri (2011), öz sermaye karlılığı, yönetimin kalitesi, yatırımın karlılığı ve fiyat-kazanç oranının Hintli yatırımcıların hisse senedi seçerken en çok dikkate aldıkları faktörler olduklarını belirlemişlerdir. Das (2012) ise, Hindistan'ın Guwahati borsasında küçük yatırımcıların hisse senedi yatırım davranışını belirlemek üzere bir çalışma gerçekleştirmiştir. Yatırım sürecinde dikkate alınabilecek 38 faktörü kullanılarak 100 yatırımcıya anket uygulanmıştır. Frekans dağılımlarına göre sonuçlar küçük yatırımcılar için en önemli faktörlerin sırasıyla; şirketin finansal tablolarının durumu, diğer insanların tavsiyeleri, kamuya açık bilgiler, şirketin karlılığı olduğunu ortaya koymuştur. Hindistan'da yapılan bir diğer çalışmada Velumoni ve Rau (2015), Das(2012)'nin en önemli faktörler arasında gösterdiği tavsiyelerin yatırımcı davranışları üzerinde pekte etkisi olmadığı bulgusuna ulaşmıştır. Bombay borsasında gerçekleştirilen çalışmada yatırımcılar için en önemli faktörün muhasebe bilgileri olduğu tespit edilmiştir.

Türkiye'de ise daha çok içsel faktörlerin kullanıldığı ya da dışsal faktörler olarak cinsiyet, yaş, gelir seviyesi gibi demografik ve sosyo-ekonomik faktörlerin dikkate alındığı çalışmaların yapıldığı görülmüştür. Dolayısıyla yerli literatürde dışsal olarak kabul edilen faktörlerin aynı şekilde kullanıldığı bir uygulamaya rastlanmamakla beraber, bu kısımda konuya ilişkili bulunan benzer çalışmalardan örneklere yer verilmiştir. Bu kapsamda bireysel yatırımcıların hisse senedi alım-satım kararlarını Afyonkarahisar ilinde yaptığı bir anket ile değerlendirme çalışan Hastürk (2014), demografik özellikler ve hisse senedi tercihini ölçmeye yönelik 24 soru ile 116 kişiden görüş almıştır. Araştırmanın sonucunda yatıımcıların yatırım kararlarını vermelerindeki 
en büyük etmenin, aracı kurum tavsiyeleri olduğu ve katılımcıların \%46,6'sı yatırım kararı verirken, aracı kurum tavsiyelerini dikkate aldığı tespit edilmiştir. Ayrıca katılımcıların $\% 25^{\prime}$ inin ise arkadaş tavsiyesini dikkate aldıkları da önemli bir bulgu olarak sunulmuştur.

Küden (2014), bireysel yatırımcı davranışlarını davranışsal finans açısından ele almış ve 437 katılımcıya yönelttikleri sorularla en çok kullanılan yatırım araçlarının sırasıyla; altın, döviz, hisse senedi ve mevduat olduğunu tespit etmişlerdir. Sonuçlar yatırımcıların en fazla ekonomi (TV) kanallarındaki tavsiyelerden etkilendikleri sonrasında ise kendi yaptıkları teknik ve temel analizlere güvendiklerini ortaya koymuştur. Ayrıca yatırımcılar, geçmiş fiyat hareketlerinin gelecekteki fiyatları tahmin etmede kullanılabileceğini belirtmişlerdir.

Yeşildağ ve Özen (2015), Uşak ilindeki bireysel hisse senedi yatırımcılarının yatırım kararlarını etkileyen demografik ve sosyo-ekonomik faktörleri tespit etmek üzere yaptıkları analiz sonucunda yatırımcıları rasyonel olmayan bazı davranışları olduğunu ortaya çıkarmışlardır. Bu davranışlar; yatırımcıların alım satım işlemlerinde kısa vadeli düşünmeleri, hisse senedi yatırımı ve hisse senedi tercihi yapmadan önce başvurulması gereken temel ve teknik analiz gibi yöntemlerin daha az bir kesim tarafından uygulanmakta olması şeklinde sıralanmıştır.

Bodur (2016), İzmir ili ve ilçelerindeki bireysel yatırımcıların kararlarını etkileyen 21 faktörü aşırı güven açısından değerlendirmiştir. 398 bireysel yatırımcıya anket yönteminin uygulandığı çalışmanın bulguları incelendiğinde, frekans dağılımlarına göre yatırım aracı tercihini etkileyen en önemli faktörün getiri oranı olduğu, getiri oranı ile ilgili beklentilerin demografik faktörler açısından farklılık göstermediği, yatırım aracının risk düzeyi ile ilgili düşüncelerin, getiri oranı ile ilgili beklentiler faktöründen sonra en önemli etken olduğu tespit edilmiştir.

Aşıkoğlu ve Böyükaslan (2016), bireysel yatırımcı kararlarını etkileyen faktörlerin davranışsal finans kapsamında değerlendirilmesi amacıyla Afyonkarahisar'da bir çalışma gerçekleştirmişler. Yatırımcıların sosyo-demografik özelliklerinin, finansal yatııım alışkanlıklarının ve yatırım tutumlarının ortaya konulması amacıyla 460 katılımcı ile bir anket çalışması yapmışlardır. Keşfedici faktör analizinin uygulandığı çalışma sonucunda bireysel yatırımcıların, çoğunlukla duygusal finansal davranışlar sergiledikleri ve kendine olan güvene ilişkin eğilimlerinin güçlü bir şekilde hissedildiği tespit edilmiştir. Benzer şekilde Aydın ve Ağan (2016), 600 bireysel yatırımcıya uyguladıkları 41 soruluk anket sonucunda, bireysel yatırımcıların finansal yatırım kararlarını alırken davranışsal eğilimlerden etkilendiklerini, sistematik hatalar yaptıklarını ve irrasyonel davranışlar sergilendikleri belirlemiştir.

\section{Araştırma Metodolojisi}

Çalışmanın bu bölümünde, ilk olarak araştırma kapsamına dahil edilmiş olan bireysel yatırımcı kararlarını etkileyen faktörlere yer verilmekte; sonrasında ise, araştırma modelinde kullanılan yöntemlere dair açıklayıcı bilgiler sunulmaktadır.

\subsection{Araştırma Değişkenleri}

Bireysel yatırımcı kararlarını etkileyen faktörleri DEMATEL-ANP yöntemiyle değerlendirmeyi amaçlayan bu çalışmada, araştırma değişkenleri literatür bölümünde yer alan çalışmalardan yararlanılarak oluşturulmuştur. Bu doğrultuda mevcut çalışmada dikkate alınan ana ve alt kriterler ile kullanıldıkları kaynaklar Tablo 1'de gösterilmiştir. 
Tablo 1. Çalışmada Kullanılan Kriterler ve Kaynakları

\begin{tabular}{|c|c|c|}
\hline \multicolumn{2}{|r|}{ Ana ve Alt Kriterler } & İlgili Çalışmalar \\
\hline \multicolumn{3}{|c|}{ Muhasebe Bilgileri (M) } \\
\hline M1. & Beklenen Kazanç & $\begin{array}{l}\text { Nagy ve Obenberger (1994), Merikas vd. (2004), Al-Tamimi } \\
\text { (2006), Das (2012), Obamuyi (2013) }\end{array}$ \\
\hline M2. & Beklenen Temettü & $\begin{array}{l}\text { Nagy ve Obenberger (1994), Merikas vd. (2004), Al-Tamimi } \\
\text { (2006), Bennet vd (2011), Das (2012) }\end{array}$ \\
\hline M3. & $\begin{array}{l}\text { Firmanın Endüstriye Göre } \\
\text { Performansı }\end{array}$ & Merikas vd. (2004), Al-Tamimi (2006), Das (2012) \\
\hline M4. & Fiyat/Kazanç Oranı & Bennet vd (2011), Das (2012), Hossain ve Nasrin (2012) \\
\hline M5. & Özsermaye Karlılık Oranı & $\begin{array}{l}\text { Bennet vd. (2011), Das (2012), Edirisinghe ve Zhang (2007), } \\
\text { Hossain ve Nasrin (2012) }\end{array}$ \\
\hline \multicolumn{3}{|c|}{ Tavsiyeler (T) } \\
\hline & Aracı kurum tavsiyesi & $\begin{array}{l}\text { Nagy ve Obenberger (1994), Merikas vd. (2004), Al-Tamimi } \\
\text { (2006), Bennet vd. (2011), Das (2012), Obamuyi (2013), } \\
\text { Hossain ve Nasrin (2012) }\end{array}$ \\
\hline $\mathrm{T} 2$. & $\begin{array}{l}\text { Arkadaş ya da aile } \\
\text { tavsiyesi }\end{array}$ & $\begin{array}{l}\text { Nagy ve Obenberger (1994), Merikas vd. (2004), Al-Tamimi } \\
\text { (2006), Bennet vd. (2011), Das (2012), Obamuyi (2013), } \\
\text { Hossain ve Nasrin (2012) }\end{array}$ \\
\hline T3. & $\begin{array}{l}\text { Hissedarların } \\
\text { çoğunluğunun fikirleri }\end{array}$ & Merikas vd.. (2004), Al-Tamimi (2006), Das (2012) \\
\hline \multicolumn{3}{|c|}{ Kişisel Finansal Ihtiyaçlar (K) } \\
\hline K1. & Hızlıca zengin olmak & $\begin{array}{l}\text { Merikas vd. (2004), Al-Tamimi (2006), Das (2012), Obamuyi } \\
\text { (2013) }\end{array}$ \\
\hline & $\begin{array}{l}\text { Yüksek getiri için risk } \\
\text { almaya istekli olmak }\end{array}$ & Hossain ve Nasrin (2012) \\
\hline K3. & $\begin{array}{l}\text { Çeşitlendirme ihtiyacında } \\
\text { olmak }\end{array}$ & Merikas vd. (2004), Al-Tamimi (2006) \\
\hline \multicolumn{3}{|c|}{ Firmaya Özgü Bilgiler (F) } \\
\hline F1. & Firmanın yaşı & Hossain ve Nasrin (2012) \\
\hline F2. & Firmanın ünü & $\begin{array}{l}\text { Nagy ve Obenberger (1994), Merikas vd. (2004), Al-Tamimi } \\
\text { (2006), Hossain ve Nasrin (2012) }\end{array}$ \\
\hline F3. & Firmanın büyüklüğü & Bennet vd (2011), Hossain ve Nasrin (2012) \\
\hline F4. & $\begin{array}{l}\text { Firmanın içinde bulunduğu } \\
\text { endüstri kolu }\end{array}$ & Hossain ve Nasrin (2012) \\
\hline \multicolumn{3}{|c|}{ Diğer Faktörler (D) } \\
\hline D1. & $\begin{array}{l}\text { Bir şirketin hisse } \\
\text { senetlerindeki son fiyat } \\
\text { hareketi }\end{array}$ & $\begin{array}{l}\text { Nagy ve Obenberger (1994), Merikas vd. (2004), Al-Tamimi } \\
\text { (2006), Das (2012) }\end{array}$ \\
\hline & $\begin{array}{l}\text { Hisse senetlerinin uygun } \\
\text { fiyatlı olması }\end{array}$ & $\begin{array}{l}\text { Nagy ve Obenberger (1994), Merikas vd. (2004), Al-Tamimi } \\
\text { (2006), Hossain ve Nasrin (2012) }\end{array}$ \\
\hline D3. & $\begin{array}{l}\text { Politikacılar ve devlet } \\
\text { yetkilileri tarafından } \\
\text { yapılan açıklamalar }\end{array}$ & $\begin{array}{l}\text { Merikas vd. (2004), Al-Tamimi (2006), Hossain ve Nasrin } \\
\text { (2012) }\end{array}$ \\
\hline D4. & $\begin{array}{l}\text { Büyük piyasaların } \\
\text { endekslerinde yaşanan } \\
\text { dalgalanma ve gelişmeler }\end{array}$ & Merikas vd. (2004), Al-Tamimi (2006) \\
\hline D5. & $\begin{array}{l}\text { Mevcut durumdaki } \\
\text { ekonomik göstergeler }\end{array}$ & $\begin{array}{l}\text { Merikas vd. (2004), Al-Tamimi (2006), Das (2012), Obamuyi } \\
\text { (2013), Nagy ve Obenberger (1994), }\end{array}$ \\
\hline D6. & $\begin{array}{l}\text { Şirket performansının tüm } \\
\text { piyasa performansına } \\
\text { duyarlılığı }\end{array}$ & Hossain ve Nasrin (2012) \\
\hline
\end{tabular}




\subsection{Araştırma Yöntemi}

Bireysel yatırımcıların hisse senedi seçimi sırasında sergiledikleri davranışları etkileyen ana ve alt faktörlerin araştırıldığı bu çalışmada, söz konusu faktörler arasında bir değerlendirme yapılabilmesi için çok kriterli karar verme yöntemlerinden yararlanılmıştır.

Çok kriterli karar verme problemlerinin çözümünde en sık kullanılan ve ilk akla gelen yöntem olan AHP (Saaty, 1980), kriterler arasında bağımsız bir ilişkinin olduğunu varsaymaktadır. Ancak gerçek hayatta böyle bir varsayımdan söz edilmesi pek mümkün değildir (Ho vd., 2011: 19). Dolayısıyla AHP'nin yetersiz kaldığı kriterler arasındaki etkileşim ve geri besleme sorunun çözümü için AHP'nin daha genel bir şekli olarak kabul edilen ANP (Saaty, 1996) geliştirilmiştir. Böylece ANP sadece belirli ana kriterler altındaki alt kriterlerin ikili karşılaştırmalarına değil, birbiri ile etkileşimde olan tüm alt kriterlerin bağımsız olarak da karşılaştırılabilmelerine imkân vermiştir. Tüm bu olumlu yönlerinin yanı sıra ANP'nin de yetersiz kaldığı bazı noktalar ortaya çıkmıştır. Öyle ki ANP, kriterler arasındaki farklı etki seviyelerine rağmen, süpermatrisin normalize edilmesinde her bir kriterin ağırlığının eşit olduğunu varsaymaktadır (Ou Yang vd., 2008:160). Bu olumsuzluğun giderilebilmesi amacıyla mevcut çalışmada DEMATEL yönteminden yararlanılmış ve ANP'nin kriterler arasındaki farklı etki derecelerinin ortaya koyulması hususundaki eksikliği giderilmiştir. Daha açık bir ifadeyle, çalışmada, ilk olarak DEMATEL yöntemi uygulanmış ve etki dereceleri belirlenmiştir. Ardından belirlenen etki dereceleri, ANP'deki süper matrise entegre edilmişsir. Böylece çalışmada DEMATEL ve ANP yöntemleri birbirlerinin tamamlayıcısı olarak kullanılmıştır.

\subsubsection{DEMATEL Yöntemi}

Çok ölçütlü karar verme yöntemlerinden olan DEMATEL (Decision Making Trial and Evaluation Laboratory), 1972 ve 1976 yılları arasında Cenevre Battelle Memorial Enstitüsü tarafından geliştirilmiştir (Wu vd., 2010: 5220). DEMATEL yöntemi; karmaşık ve birbirine geçmiş problem kümelerinin anlaşımasını kolaylaştırmak, bu kriterlerin birbirleri arasındaki etkileşiminin yönünü belirlemek ve bu kriterleri etki bakımından önceliklendirmek gibi konulara katkıda bulunmak amacıyla ortaya çıkarılmıştır (Shieh vd., 2010: 279). DEMATEL yöntemi, nedensel ilişkileri daha iyi anlamak için ilgili kriterleri sebep-sonuç şeklinde iki gruba ayırır ve bu ilişkileri anlaşılabilir yapısal bir modele dönüştürür (Wu, 2008: 830). Diğer kriterler üzerinde daha çok etkisi ve yüksek önceliği olan kriterleri sebep kriterleri, diğer kriterlerden daha çok etkilenen, düşük önceliği olan kriterleri ise sonuç kriterleri olarak tanımlar (Tseng ve Lin, 2009: 520). Bu çalışmada, DEMATEL yöntemi, kriterler arasındaki farklı etki derecelerini belirlemenin yanı sıra, literatüre uygun olarak, bu yöntemden elde edilen toplam etki matrisinin normalize edilerek ANP'deki ağılıklandırılmamış süpermatrise entegre edilmesi amacıyla da kullanılmaktadır (Chen ve Tzeng, 2011; Wang ve Tzeng, 2012; Hsu vd.,2012). Söz konusu yöntem, aşağıda 4 adımda özetlenmektedir (Chiu vd., 2006; Wu, 2008; Tzeng, 2009; Aksakal ve Dağdeviren, 2010; Hsu vd., 2012).

\section{Adım: Direkt Etki Matrisinin Oluşturulması}

Direkt etki matrisi oluşturulurken konu ile ilgili uzmanlardan oluşan bir gruptan, ikili karşılaştırma skalasını kullanarak kriterlerin birbirleri üzerindeki direkt etki derecelerini puanlandırmaları istenir. Bu skala on bir seviyeye (0-10) kadar düzenlenebilir ancak literatürde en yaygın kullanılanı Tablo 2' de gösterilen, beş seviyeden (0-4) oluşan ikili karşılaştırma skalasıdır.

Tablo 2. İkili Karşılaştırma Skalası

\begin{tabular}{cc} 
Sayısal Değerler & Tanım \\
\hline 0 & Etkisiz \\
1 & Düşük etki \\
2 & Orta etki \\
3 & Yüksek etki \\
4 & Çok yüksek etki
\end{tabular}


Alınan cevaplar göre her bir uzman için nxn'lik bir D matrisi oluşturulur. $a_{i j}$ simgesi uzmanların i kriterinin $\mathrm{j}$ kriterini ne derecede etkilediğine ilişkin görüşünü yansıtır. Her bir uzman için oluşturulan matrislerin eşit ağırlıklı olduğu kabul edilerek oluşturulan matrislerin ortalamaları alınır ve tek bir direkt etki matrisi elde edilir.

\section{Adım: Direkt Etki Matrisinin Normalize Edilmesi} oluşturulur.

Direkt etki matrisine bağlı olarak, aşağıdaki eşitlik yardımıyla normalize direkt etki matrisi (N)

$$
\begin{aligned}
& \mathrm{N}=\mathrm{z} \times \mathrm{D} \\
& z=1 / \max \left\{\max _{1 \leq i \leq n} \sum_{j=1}^{n} a_{i j}, \max _{1 \leq j \leq n} \sum_{i=1}^{n} a_{i j}\right\}
\end{aligned}
$$

Bu eşitliğe göre; birinci adımda oluşturulan direkt etki matrisindeki satırlar ve sütunlar ayrı ayrı toplanır ve en yüksek olan değer 1'e bölünerek " $z$ " değeri elde edilir ve ardından elde edilen bu değer, matristeki tüm hücrelerle çarpılır.

\section{Adım: Toplam Etki Matrisinin Oluşturulması}

Normalleştirilmiş direkt etki matrisi elde edildikten sonra aşağıdaki eşitlik kullanılarak toplam etki matrisi $\left(T_{c}\right)$ oluşturulur. Bu eşitlikte yer alan I, birim matrisi temsil etmektedir.

$$
T_{C}=N(I-N)^{-1}
$$

\section{Adım: Etki Yönlerinin Belirlenmesi ve Graf Diyagramının Oluşturulması}

T matrisindeki sütunlar toplamı c, satırlar toplamı $r$ olarak kabul edilir. Belirlenen satır ve sütun değerleri yardımıyla $\mathrm{R}-\mathrm{C}$ ve $\mathrm{R}+\mathrm{C}$ değerleri hesaplanır. Bu değerler her bir kriterin diğer kriterleri ne kadar etkilediğini ve diğer kriterlerden ne kadar etkilendiğini gösterir. Mevcut çalışmada alt kriterlere ait toplam etki matrisi $T_{C}$ ile gösterilirken ana kriterlere ait toplam etki matrisi $T_{D}$ ile gösterilmiştir.

$$
\begin{aligned}
& \mathrm{T}=\left[t_{i j}\right]_{n x n}, \quad \mathrm{i}, \mathrm{j}=1,2, \ldots \ldots \ldots \ldots . ., \mathrm{n} \\
& R=\left[\sum_{i=1}^{n} t_{i j}\right]_{n x 1}=\left[t_{i}\right]_{n x 1} \\
& C=\left[\sum_{j=1}^{n} t_{i j}\right]_{n x 1}=\left[t_{j}\right]_{n x 1}
\end{aligned}
$$

" $\mathrm{R}+\mathrm{C}$ " değeri, kriterler arasındaki toplam ilişkiyi yani diğer kriterleri etkileme ve diğer kriterlerden etkilenme oranını toplam olarak gösterirken, "R-C" değeri ise gönderici ve alıcı grupları belirlemek üzere kullanılır. Buna göre "R-C" değeri pozitif olan kriterler gönderici, "R-C" değeri negatif olan kriterler ise alıcı olarak adlandırıırlar. Tüm bu etkiler kullanılarak DEMATEL yönteminde kriterler arasındaki ilişkiyi görsel olarak ortaya koymak amacıyla etki yönlü bir graf diyagramı düzenlenir.

Mevcut çalışmada kullanılan DEMATEL-ANP hibrid yaklaşımının gereği olarak, DEMATEL yöntemi sadece ağılıklandırımamış süpermatrisi elde etmek üzere kullanılmaktadır. Dolayısıyla DEMATEL yönteminden elde edilen toplam etki matrisini takiben ANP adımları uygulanmıştır. 


\subsubsection{ANP Yöntemi}

Kriterler arasındaki karşılıklı ilişkileri ortaya koymak ve geri besleme sorununu çözmek amacıyla geliştirilen ANP (Analytic Network Process) birçok karar verme probleminin çözümünde başarıyla uygulanabilmektedir (Liou vd., 2007: 243). Geleneksel ANP yönteminden farklı olarak, bu çalışmada, DEMATEL-ANP modeli gereğince süpermatrisin ağırlıklandırılmasında ve ağırlıklandırılmamış süpermatrisin elde edilmesinde DEMATEL yönteminden elde edilen toplam etki matrislerinden yararlanılmıştır. Dolayısıyla ANP, DEMATEL yöntemini takiben 3 adımdan oluşmaktadır (Ou Yang vd., 2008; Wang ve Tzeng, 2012; Hsu vd., 2012).

\section{Adım: Ağırlıklandırılmış Süpermatrisin Oluşturulması}

DEMATEL yönteminden elde edilen alt kriterlere ait toplam etki matrisi $\left(T_{C}\right)$, her bir alt kriterin kendi ana kriter gurubuna ait satır toplamlarına (dc) bölünmesiyle normalize edilir. Normalize edilen toplam etki matrisinin $\left(\mathrm{T}_{\mathrm{C}}^{\alpha}\right)$ transpozesi alınarak ağırlıksız süpermatris elde edilir $(\mathrm{W})$.

$$
\left.\mathrm{T}_{\mathrm{C}}=\begin{array}{lll}
\hline t_{c 11 . .} & t_{c 1 j .} & t_{c 1 n} \\
\hline t_{c i 1 . \cdot} & t_{c i j \cdot .} & t_{c i n} \\
t_{c n 1 .} & t_{c n j .} & t_{c n n}
\end{array}\right) \rightarrow d_{c 1}=\sum_{j=1}^{n} t_{c 1 j}
$$

$t_{c i j}^{\alpha}=t_{c i j} / d_{c i}$

Eşitliği yardımıyla alt kriterlere ait toplam etki matrisi $\left(T_{c}\right)$ normalize edilir. Normalize edilen toplam etki matrisi " $\mathrm{T}_{\mathrm{C}}^{\alpha ”}$ ile gösterilmiştir.

$$
\begin{aligned}
& \mathrm{T}_{\mathrm{C}}^{\alpha}=\left(\begin{array}{lll}
t_{c 11} / d_{c 1 . .} & t_{c 1 j} / d_{c 1 . .} & t_{c 1 n} / d_{c 1} \\
t_{c i 1} / d c_{i} . . & t_{c i j} / d c_{i} . & t_{c i n} / d_{c i} \\
t_{c n 1} / d_{c n} . & t_{c n j} / d c_{n} \ldots . & t_{c n n} / d c_{n}
\end{array}\right) \longrightarrow \begin{array}{lll}
t_{c 11}^{\alpha} \ldots & t_{c 1 j}^{\alpha} \ldots & t_{c 1 n}^{\alpha} \\
t_{c i 1}^{\alpha} \ldots & t_{c i j}^{\alpha} \ldots & t_{c i n}^{\alpha} \\
t_{c n 1 . .}^{\alpha} & t_{c n j}^{\alpha} \ldots & t_{c n n}^{\alpha}
\end{array} \\
& W=\left(T_{C}^{\alpha}\right)^{I}=\left(\begin{array}{ccc}
W_{1 j} \cdot & W_{i j \cdot .} & W_{n j} \\
W_{1 n . .} & W_{i n . .} & W_{n n}
\end{array}\right)
\end{aligned}
$$

\section{Adım: Süpermatrisin Ağırlıklandırılması}

Her bir kriterin ağırlı̆ının eşit olduğunu varsayan ANP'nin rasyonel olmayan bu varsayımını elimine etmek amacıyla, süpermatris ağırlıklandırılırken, DEMATEL yönteminden elde edilen ana kriterlere ait toplam etki matrisinden $\left(T_{D}\right)^{1}$ faydalanılır. Ağırlıklandııılmış süper matrise ulaşmak için ana kriterlere ait toplam etki matrisi normalize edilir. Bu matris $\mathrm{T}_{\mathrm{D}}^{\alpha}$ simgesi ile gösterilmektedir.

$t_{D}^{\alpha i j}=t_{D}^{i j} / d_{i}$ 


$$
\mathrm{T}_{\mathrm{D}}^{\alpha}=\left(\begin{array}{ccc}
t_{D}^{11} / d_{1} . . & t_{D}^{1 j} / d_{1} . . & t_{D}^{1 n} / d_{1} . . \\
t_{D}^{i 1} / d_{i} . . & t_{D}^{i j} / d_{i} . . & t_{D}^{i n} / d_{i} . . \\
t_{D}^{n 1} / d_{n} . . & t_{D}^{n j} / d_{n} . . & t_{D}^{n n} / d_{n} . .
\end{array}\right) \longrightarrow\left(\begin{array}{cccc}
t_{D}^{\alpha 11} & \ldots & t_{D}^{\alpha 1 j} \ldots . & t_{D}^{\alpha 1 n} \\
\vdots & \vdots & \vdots \\
t_{D}^{\alpha i 1} \ldots & t_{D}^{\alpha i j} \ldots & t_{D}^{\alpha i n} \\
\vdots & \vdots & \vdots \\
t_{D}^{\alpha n 1} . . & t_{D}^{\alpha n j} \ldots & t_{D}^{\alpha n n}
\end{array}\right)
$$

Bir sonraki aşamada ise, ağırlıklandırılmamış süpermatristeki her bir alt kriter, ilgili olduğu ana kritere ait normalize edilmiş toplam etki matrisindeki değerle çarpılır. Elde edilen yeni matris ağırlıklandırılmış süpermatris $\left(\mathrm{W}^{\alpha}\right)$ olarak adlandırılır.

$$
\mathrm{W}^{\alpha}=\left(\begin{array}{ccc}
t_{D 11}^{\alpha} \mathrm{X} W_{11 . \cdot} & t_{D \mathrm{i} 1}^{\alpha} \mathrm{X} W_{1 j} . . & t_{D 1 n}^{\alpha} \mathrm{X} W_{1 n} \\
\vdots & \vdots & \vdots \\
t_{D 1 j}^{\alpha} \mathrm{X} W_{\mathrm{I} 1 . \cdot} & t_{D i j}^{\alpha} \mathrm{XW}_{i j . \cdot} & t_{D n j}^{\alpha} \mathrm{X} W_{i n} \\
\vdots & \vdots & \vdots \\
t_{D 1 n}^{\alpha} \mathrm{X} W_{n 1 . .} & t_{D i n}^{\alpha} \mathrm{X} W_{n j} . . & t_{D n n}^{\alpha} \mathrm{X} W_{n n}
\end{array}\right)
$$

\section{Adım: Limit Süpermatrisin Oluşturulması}

Ağırlıklandırılmış süpermatrisin belli bir kuvvetinin (k) alınması ile oluşturulan ve eşitlik (14) yardımıyla hesaplanan limit süpermatris, kriterlerin birbirleri üzerindeki uzun dönemli göreceli etkilerinin ölçülmesi amacıyla kullanılmaktadır. Bu nedenle, ağırlıklandırımış süpermatris, her satırı belli bir değerde sabit kalana kadar kendisi ile çarpılır. Elde edilen limit süpermatris karşılaştırılan kriterler arasında önem ağırııları bakımından bir sıralama yapılmasına, dolayısıyla karar sürecini etkileyen en önemli kriterin belirlenmesine yardımcı olmaktadır.

$$
\left(\lim _{h \rightarrow \infty}\left(W^{\alpha}\right)^{h}\right.
$$

\section{Araştırma Bulguları}

Ampirik araştırmada, metodolojide verilen DEMATEL-ANP hibrid yöntemine ait adımlar takip edilerek bireysel yatırımcıların karar verirken dikkate aldıkları ana ve alt kriterler arasındaki ilişkiler belirlenmiş ve en önemli kriterlerin hangileri olduğu tespit edilmiştir.

\subsection{Yatırımcı Kararlarını Etkileyen Kriterler Arasındaki Ilişkilerin DEMATEL Yöntemiyle Ölçülmesi}

Bireysel hisse senedi yatırımcılarının kararlarını etkileyen faktörler üzerine yapılan bu çalışmada, ilk olarak DEMATEL yöntemi uygulanmış ve direkt etki matrisi düzenlenerek uygulamaya başlanmıştır. Direkt etki matrisi oluşturulurken alanında uzman 4 broker, 4 yatırım danışmanı ve 10 yılı aşkın süredir hisse senedi alım satımı yapan 6 bireysel yatırımcı olmak üzere 14 kişilik bir uzman gruptan destek alınmıştır.

Bu kapsamda ilk olarak çalışmada kullanılan kriterler arasında, ikili karşılaştırma yapılmasını imkan veren bir anket hazırlanmış ve uzman grubun anketleri doldurması sağlanmıştır. Uzamaların anketlere verdikleri cevaplar doğrultusunda oluşturulan matrislerin ortalamaları alınarak, Ek 1. de gösterilen Tablo 3'te yer alan direkt etki matrisi (D) elde edilmiş ve eklerde gösterilmiştir.

DEMATEL yönteminin gereği olarak kriterlerine ilişkin direkt etki matrisi, eşitlik (1) ve (2) yardımıyla normalize edilmiş ve Ek 2.'de gösterilen Tablo 4'teki normalize direkt etki matrisi (N) oluşturulmuştur.

Normalize edilmiş direkt etki matrisi, eşitlik (3) kullanılarak Ek 3.'de gössterilen Tablo 5'te verilen toplam etki matrisine $\left(T_{C}\right)$ dönüştürülmüştür. Ayrıca 5 ana kritere ilişkin direkt etki matrisi, uzman gruptan alınan cevaplar sonrasında oluşturulmuş ve Tablo 6'da gösterilmiştir. 
Tablo 6. Ana Kriterlere Iliş̧kin Direk Etki Matrisi (A)

\begin{tabular}{|l|ccccc|}
\cline { 2 - 6 } \multicolumn{1}{c|}{} & $\mathbf{M}$ & $\mathbf{T}$ & $\mathbf{K}$ & $\mathbf{F}$ & $\mathbf{D}$ \\
\hline $\mathbf{M}$ & 0,000 & 3,143 & 2,643 & 2,429 & 2,714 \\
$\mathbf{T}$ & 2,143 & 0,000 & 2,429 & 2,214 & 2,286 \\
$\mathbf{K}$ & 2,143 & 2,071 & 0,000 & 2,786 & 2,214 \\
$\mathbf{F}$ & 2,929 & 2,643 & 2,357 & 0,000 & 2,714 \\
$\mathbf{D}$ & 2,429 & 2,214 & 2,500 & 2,077 & 0,000 \\
\hline
\end{tabular}

Ana kriterlere ilişkin direkt etki matrisine metodolojide anlatılan adımlar uygulanarak, Tablo 7'de verilen toplam etki matrisi $\left(T_{D}\right)$ oluşturulmuştur. Aynı tabloda satır /sütun toplamları ve farkları olarak $R+C$ ve $\mathrm{R}-\mathrm{C}$ değerlerine de yer verilmiştir.

Tablo 7. Ana Kriterlere Ilişskin Toplam Etki Matrisi ( $\left.T_{D}\right)$ ve R+C / R-C Değerleri

\begin{tabular}{|l|ccccccccc|}
\cline { 2 - 10 } \multicolumn{1}{c|}{} & $\mathbf{M}$ & $\mathbf{T}$ & $\mathbf{K}$ & $\mathbf{F}$ & $\mathbf{D}$ & $\mathbf{R}$ & $\mathbf{C}$ & $\mathbf{R}+\mathbf{C}$ & $\mathbf{R}-\mathbf{C}$ \\
\hline $\mathbf{M}$ & 1,711 & 1,999 & 1,951 & 1,876 & 1,952 & 9,489 & 8,585 & 18,074 & 0,904 \\
$\mathbf{T}$ & 1,636 & 1,525 & 1,692 & 1,626 & 1,681 & 8,161 & 8,896 & 17,058 & $-0,735$ \\
$\mathbf{K}$ & 1,665 & 1,713 & 1,538 & 1,688 & 1,705 & 8,309 & 8,806 & 17,116 & $-0,497$ \\
$\mathbf{F}$ & 1,897 & 1,942 & 1,906 & 1,667 & 1,926 & 9,339 & 8,496 & 17,836 & 0,843 \\
$\mathbf{D}$ & 1,675 & 1,717 & 1,719 & 1,639 & 1,531 & 8,282 & 8,796 & 17,078 & $-0,514$ \\
\hline
\end{tabular}

\subsection{Yatırımcı Kararlarını Etkileyen Kriterlerin Bütünleştirilmiş DEMATEL-ANP Yöntemiyle} Ağırlıklandırııması

Bireysel yatırımcıların karar verirken dikkate aldıkları kriterler arasında bir önem sıralaması yapabilmek ve en önemli kriteri belirleyebilmek amacıyla DEMATEL yöntemini takiben ANP yöntemi uygulanmıştır. Bu paralelde DEMATEL yönteminden elde edilen toplam ilişki matrisindeki veriler kullanılarak Ek 4'de gösterilen Tablo 8'de verilen ağırlıklandırılmamış süper matris elde edilmiştir.

Süpermatrisin ağırlıklandırılması işlemi için ise, DEMATEL yönteminden elde edilen ana kriterlere ait toplam etki matrisi $\left(T_{D}\right)$ normalize edilmiş $\left(T_{D}^{\alpha}\right)$ ve ağırlıklandırılmamış süpermatristeki her bir alt kriter, ilgili olduğu ana kritere ait normalize edilmiş toplam etki matrisindeki değerle çarpılmıştır. Tüm işlemler excel ile gerçekleştirilmiştir. Normalize edilme yoluyla ana kriterlere için hesaplanan ağırlıklar $\left(T_{D}^{\alpha}\right)$ Tablo 9'da, ağırlıklandırılmış süpermatris $\left(\mathrm{W}^{\alpha}\right)$ ise Ek $5^{\prime}$ te yer alan Tablo $10^{\prime}$ da gösterilmiştir.

Tablo 9. Ana Kriterler için Hesaplanan Ağırlıklar $\left(\mathrm{T}_{\mathrm{D}}^{\alpha}\right)$

\begin{tabular}{|l|lllll|}
\cline { 2 - 6 } \multicolumn{1}{c|}{} & $\mathbf{M}$ & $\mathbf{T}$ & $\mathbf{K}$ & $\mathbf{F}$ & $\mathbf{D}$ \\
\hline $\mathbf{M}$ & 0,180 & 0,211 & 0,206 & 0,198 & 0,206 \\
$\mathbf{T}$ & $\mathbf{0 , 2 0 1}$ & 0,187 & 0,207 & 0,199 & 0,206 \\
$\mathbf{K}$ & 0,200 & 0,206 & 0,185 & 0,203 & 0,205 \\
$\mathbf{F}$ & 0,203 & 0,208 & 0,204 & 0,179 & 0,206 \\
$\mathbf{D}$ & 0,202 & 0,207 & 0,208 & 0,198 & 0,185 \\
\hline
\end{tabular}

ANP yönteminin son aşamasında excel yardımı ile limit süpermatris hesaplanmış ve Ek 6.'da yer alan Tablo 11'da gösterilmiştir.

Bireysel yatırımcıların hisse senedi seçim sürecindeki davranışlarını etkileyen faktörler arasında bir önem sıralaması yapılması ve en önemli kriterin ortaya koyulması amacıyla gerçekleştirilen DEMATEL-ANP yöntemi sonucunda elde edilen limit süpermatris değerlendirilmiştir. Limit süpermatriste yer alan her satır değeri, sermaye yapısı kararları alınırken dikkate alınan kriterler için belirlenen ağırıkları temsil etmekte ve en yüksek ağırlığa sahip olan kriterin en önemli kriter olduğu ifade edilebilmektedir. Bu doğrultuda Tablo 
$11^{\prime}$ deki limit süpermatris incelendiğinde en önemli kriterin $0,071^{\prime}$ lik ağırlık değeriyle aracı kurum tavsiyesi (T1) kriteri olduğu görülmektedir. Yüksek getiri için risk almaya istekli olmak (K2), hızlıca zengin olmak (K1), arkadaş ve aile tavsiyesi (T2), hissedarların çoğunluğunun fikirleri (T3) ve çeşitlendirme ihtiyacı (K3) kriterlerinin ise, aracı kurum tavsiyesi kriterini takiben sırasıyla en önemli kriterler oldukları söylenebilmektedir. Diğer taraftan $0,033^{\prime} \mid u ̈ k$ ağırlıkla şirket performansının tüm piyasa performansına duyarlılı̆ı (D6), büyük piyasaların endekslerinde yaşanan dalgalanma ve gelişmeler (D4) ve hisse senetlerinin uygun fiyatlı olması (D2) en az öneme sahip kriterler olarak dikkat çekmektedir. Politikacılar ve devlet yetkililerince yapılan açıklamalar (D3), mevcut durumdaki ekonomik göstergeler (D5) ve hisse senetlerindeki son fiyat hareketi (D1) kriterleri de 0,034 'lük ağırlıkla önem sırlamasında alt sırlarda yer almaktadırlar. Önem bakımından tüm kriterleri arasında bir önceliklendirme yapıldığında ise $\mathrm{T} 1>\mathrm{K} 2>\mathrm{K} 1>\mathrm{T} 2=\mathrm{T} 3>\mathrm{K} 3>\mathrm{F} 1>\mathrm{F} 3=\mathrm{F} 4>\mathrm{F} 2>\mathrm{M} 1>\mathrm{M} 4>\mathrm{M} 5=\mathrm{M} 3>\mathrm{M} 2>\mathrm{D} 1=\mathrm{D} 3=\mathrm{D} 5>\mathrm{D} 2=\mathrm{D} 4=\mathrm{D} 6$ şeklinde bir sıralamanın ortaya çıktığı görülmektedir.

\section{Sonuç ve Değerlendirme}

Geleneksel varlık fiyatlandırma modellerinin kesitsel hisse senedi getirilerini tam olarak açıklayamaması üzerine yapılan çalışmalar, son yıllarda oldukça dikkat çeken davranışsal finans konusunu ortaya çıkarmış ve getiriler arasındaki farklılı̆ın potansiyel nedenlerinden biri olarak bireysel yatırımcıların heterojenliği gösterilmiştir. Buna göre bireysel yatırımcıların farklı kültür, eğitim seviyesi, psikolojik yapı ve bilgi düzeyine sahip olmaları nedeniyle beklentileri de farklılıklar göstermektedir. Böylece yatırımcılar verdikleri kararlarda rasyonellikten uzaklaşarak beklentilere göre hareket etmektedirler. Geleneksel finans teorilerinin göz ardı ettiği, yatırımcı davranışları etkisinin hisse senedi seçim süreci için oldukça önemli olduğunu ortaya koyan bu durum, yatıııcı davranışlarının hangi faktörlerden etkilendiğinin araştırımasını gündeme getirmiştir.

Bu çalışma, Borsa İstanbul'da işlem yapan bireysel yatırımcıların hisse senedi seçim sürecindeki davranışlarını etkileyen faktörleri incelemek üzere gerçekleştirilmiştir.

Bu kapsamda 5 ana, 21 alt faktörün kullanıldığı çalışmada 14 kişilik bir uzman gruptan alınan bilgiler kullanımış ve bireysel yatırımcı davranışlarını etkileyen faktörler arasında bir önem sıralaması yapabilmek adına DEMATEL-ANP bütünleşik yönteminden yararlanılmıştır. Elde edilen bulgular, ilk olarak tavsiyeler (T) ve ikinci olarak kişisel finansal intiyaçlar (K)'nın en önemli ana faktörler olduklarını, diğer faktörler (D)'in ise en düşük öneme sahip grup olduğunu ortaya koymuştur. Alt kriterler için bir değerlendirme yapılması durumunda ise, en önemli faktörün aracı kuruluş tavsiyesi (T1) olduğu tespit edilmiştir. Aracı kurum tavsiyesinin Türkiye'deki yatırımcılar açısından oldukça önemli olduğunu tespit eden Hastürk (2014)'ün çalışmasıyla benzerlik taşıyan bu durum, Türkiye'deki yatırımcıların aracı kurumlara önemli oranda güven duydukları göstermiştir. Yüksek getiri için risk almaya istekli olmak (K2) faktörünün ise, ikinci önemli alt faktör olduğu belirlenmiştir. Buna göre hisse senedi yatırımcılarının yatırdıkları paraları riske etmek konusunda cesur davranışlar sergilediklerini söylemek mümkündür. Önem sıralamasında üçüncü sırayı alan hızıca zengin olmak (K1) alt faktörü, kısa zamanda zengin olma güdüsüne sahip yatırımcıların hisse senedi seçiminde diğer faktörleri inmal ettiklerini düşündürmektedir. Bu durum, Merikas vd. (2004) ve Al-Tamimi (2006)'nın çalışma sonuçlarıyla da uyum göstermektedir. Hisse senedi yatırımcılar için arkadaş ve aile tavsiyesi (T2) ve hissedarların çoğunluğunun fikirleri (T3)'ün önemli olan diğer alt faktörler oldukları görülmüştür. Bir anlamda sürü psikolojisiyle benzeşen bu durum, yatırımcıların çoğunluğun alım ya da satım kararına uyumlu olarak alım ya da satıma geçtiği şeklinde yorumlanabilir. Çeşitlendirme intiyacı (K3) ise altıncı sırada önemli alt faktör olarak karşımıza çıkmaktadır. Diğer taraftan, şirket performansının tüm piyasa performansına duyarlıı̆̆ı (D6), büyük piyasaların endekslerinde yaşanan dalgalanma ve gelişmeler (D4) ve hisse senetlerinin uygun fiyatlı olması (D2) en az öneme sahip alt faktörler olarak belirlenmiştir.

Sonuç olarak uzman grup görüşleri itibariyle Türkiye'deki bireysel hisse senedi yatırımcılarının en çok önem verdikleri faktörün tavsiyeler olduğu sonrasında ise sırasıyla kişisel finansal ihtiyaçlar ve firmaya özgü bilgileri önemsedikleri görülmüştür. Farklı ülke piyasalarında yapılan çalışmaların aksine muhasebe verilerinin çok fazla önemsenmediği ve diğer faktörlerin ise en düşük öneme sahip olduğu tespit edilmiştir. 
Bireysel yatırımcı davranışlarını araştırması bakımından önem arz eden bu çalışmayı takiben, kısıtlı sayıdaki uzman grup yerine örnek kitlesi genişletilerek daha fazla bireysel yatırımcıya anket uygulaması yapılabilir, farklı tavsiye senaryoları hazırlanarak yatırımcıların nasıl kararlar vereceği araştırılabilir ve diğer ülke piyasalarında oldukça önemli bir faktör olarak görülen muhasebe verilerinin Türkiye' deki yatırımcılar için niçin fazla önemsenmediğinin üstüne gidilebilir. Ayrıca bireysel yatırımcılar için yapılan çalışma, kurumsal yatırımcılar için de yapılarak bir karşılaştırma yapılması sağlanabilir.

\section{Son Notlar}

1. Ana kriterlere ilişsin uzman gruptan alınan görüşler sonucunda oluşturulan direkt etki matrisinin, DEMATEL metodolojisindeki adımlar takip edilerek toplam etki matrisi (TD)'ne dönüştürülmesiyle elde edilir.

\section{Kaynaklar}

Aksakal, E., \& Dağdeviren, M. (2010). ANP ve DEMATEL yöntemleri ile personel seçimi problemine bütünleşik bir yaklaşım. Gazi Üniversitesi Mühendislik Mimarlık Fakültesi Dergisi, 25(4), 905-913.

Al-Tamimi, H. A. H. (2006). Factors influencing Individual investor behavior: An empirical study of the UAE financial markets. The Business Review, 5(2), 1-20.

Aşıkoğlu, H. R., \& ve Böyükaslan, A. (2016). How rational are individual investors: A factor analysis application in Turkey. Kastamonu Üniversitesi Iktisadi ve Idari Bilimler Fakültesi Dergisi, 11, 23-45.

Aydın, Ü., \& Ağan, B. (2016). Rasyonel olmayan kararların finansal yatırım tercihleri üzerindeki etkisi: Davranışsal finans çerçevesinde bir uygulama. Ekonomik ve Sosyal Araştırmalar Dergisi, 12(2), 95-112.

Barberis, N., \& Richard, T. (2003). A survey of behavioral finance. In G. Constantinides, M. Harris, and R. Stulz (ed.) Handbook of theEconomics of Finance North-Holland, Amsterdam.

Bennet, E., Selvam, M., Ebenezer, E., Karpagam, V., \& Vanitha, S. (2011). Investors' attitude on stock selection decision. International Journal of Management \& Business Studies, 1(2), 7-15.

Bodur, Y.A. (2016). Yatııımcı davranışlarını etkileyen faktörlerin aşııı güven açııından değerlendirilmesi. Pamukkale Üniversitesi Sosyal Bilimler Enstitüsü, Yayınlanmamış Yüksek Lisans Tezi, Denizli.

Chen, C. H., \& Tzeng, G.H. (2011). Assessment model for improving educational curriculum materials based on the DANP Technique with Grey Relational Analysis. International Journal of Information Systems for Logistics and Management, 6(2), 23-36.

Chiu, Y. J., Chen, H. C., Tzeng,G. H., \& Shyu, J. Z. (2006). Marketing strategy based on customer behavior for the LCDTV. International Journal of Management and Decision Making, 7(2/3), 143-165.

Das, S. K. (2012). Small investor's behaviour on stock selection decision: A case of Guwahati Stock Exchange. International Journal of Advanced Research in Management and Social Sciences, 1(2), 59-78.

Döm, S. (2003). Yatırımcı psikolojisi. Değişim Yayınları, i̇stanbul.

Estrada, J. (2001). Law and behavioral economics. http://web.iese.edu/jestrada/PDF/Research/Others/L\&BE.pdf (16.11.2017).

Edirisinghe, N. C., \& Zhang, X. (2007). Generalized DEA model of fundamental analysis and its application to portfolio optimization. Journal of Banking and Finance, 31(11), 3311-3335.

Farooq, A., Afzal, M. A., Sohail, N., \& Sajid, M. (2015). Factors affecting investment decision making: Evidence from equity fund managers and individual Investors in Pakistan. Journal of Basic and Applied Scientific Research, 5(8), 62-69.

Gunathilaka, C.(2014). Factors influencing stock selection decision: The Case of retail investors in ColomboStock Exchange. 11th International Conference on Business Management, 107-115.

Gümüş, F. B., Koç, M., \& Agalarova, M. (2013). Bireysel yatırımcıların yatırım kararları üzerinde etkili olan demografik ve psikolojik faktörlerin tespiti üzerine bir çalışma: Türkiye ve Azerbaycan Uygulaması. Kafkas Üniversitesi iktisadi ve idari Bilimler Fakültesi Dergisi, 4(6), 71-93.

Hastürk, i. V. (2014). Bireysel yatırımcıların hisse senedi alım satım kararlarının analizi: Afyonkarahisar ilinde bir uygulama. Afyon Kocatepe Üniversitesi Sosyal Bilimler Enstitüsü, Yayımlanmamış Yüksek Lisans Tezi, Afyon. 
Ho, J. W. R., Tsai, C. L., Tzeng, G. H., \& Fang, S. K. (2011). Combined DEMATEL technique with a Novel MCDM model for exploring portfolio selection based on CAPM. Expert Systems with Applications, 38(1), 16-25.

Hossain, F., \& Nasrin, S. (2012). Factors affecting selection of equity shares: The case of retail investors in Bangladesh. European Journal of Business and Management, 4(20), 110-124.

Hsu, C.H., Wang, F.K., \& Tzeng, G.H., (2012). The best vendor selection for conducting the recycled material based on hybrid MCDM model combining DANP with VIKOR. Resources, Conservation And Recycling, 66, 95-111.

Isidore, R., \& Christie P. (2015). Review of the individual equity investor's behavior in the Indian context. GeInternational Journal of Management Research, 3(6), 71-91.

Tversky, A., \& Kahneman, D. (1979). Prospect theory: An analysis of decisionunder risk. Econometrica, 47(2), $263-292$.

Kapoor, S., \& Prosad, J. M. (2017). Behavioural finance: A review, procedia computer science 122, 50-54.

Küden, M. (2014). Davranışsal finans açısından bireysel yatırım tercihlerinin değerlendirilmesi. Gediz Üniversitesi Sosyal Bilimler Enstitüsü Yüksek Lisans Tezi, İzmir.

Lee, W. S., Huang, A. Y., Chang, Y. Y., \& Cheng, C. M., (2011). Analysis of decision making factors for equity investment by DEMATEL and Analytic Network Process. Expert Systems with Applications, 38, 8375-8383.

Liou, J.J.H.,Tzeng, G.-H., \& Chang, H.-C. (2007). Airline safety measurement using a hybrid model. Air Transport Management, 13(4), 243-249.

Merikas, A. A., Merikas, A. G., Vozikis, G. S., \& Prasad, D. (2004). Economic factors and individual investor behavior: The case of the Greek Stock Exchange. Journal of Applied Business Research (JABR), 20(4), 93-98.

Nagy, R. A., \& Obenberger, R. W. (1994). Factors influencing individual investor behavior. Financial Analysts Journal, 50(4), 63-68.

Obamuyi, T. M. (2013), Factors influencing investment decisions in capital market: A study of individual investors in Nigeria. Organizations and Markets in Emerging Economies, 4 (17), 141-161.

OuYang, Y. P., Shieh, H. M., Leu, J. D., \& Tzeng, G. H. (2008). A novel hybrid MCDM Model combined with DEMATEL and ANP with applications. International Journal of Operational Research, 5(3), 160-168.

Saaty, T. L. (1996). Decision making with dependence and feedback: The analytic network process. Pittsburgh, PA: RWS Publications.

Saaty, T.L. (1980). The analytic hierarchy process. McGrawHill, New York.

Shieh, J., Wu, H., \& Huang, K. (2010). A DEMATEL method in identifying key success factors of hospital service quality. Knowledge-Based Systems, 23, 277-282.

Tseng, M. L. \& Lin, Y. H. (2009). Application of Fuzzy DEMATEL to develop a cause and effect model of municipal solid waste management in Metro Manila. Environmental Monitoring\&Assessment, 158, 519-533.

Tzeng, G.H. (2009). Combined DEMATEL technique with a hybrid novel MCDM method for creating the aspired intelligent systems. The 20th International Conference on Multiple Criteria Decision Making - MCDM, June 21-26, Chengdu, China.

Velumoni, D., \& Rau. S. S (2015). Factors Influencing Equity Investment Decision. International Business Management, $9(6), 1359-1362$.

Wang, Y.L., \& Tzeng G. H. (2012). Brand Marketing for Creating Brand Value Based on a MCDM Model Combining DEMATEL with ANP and VIKOR methods. Expert Systems with Applications, 39, 5600-5615.

Wu, W. (2008). Choosing knowledge management strategiesby using a combined anp and DEMATEL approach. Expert Systems with Applications, 35, 828-835.

Wu, H., Chen, H. K. \& Shieh, J. (2010). Evaluating performance criteria of employment service outreach program personnel by DEMATEL method. Expert System with Applications, 37, 5219-5223.

Yeşildağ, E., \& Özen, E. (2015). Uşak ilindeki hisse senedi yatırımcılarının profili ve yatırım kararlarını etkileyen demografik ve sosyo-ekonomik faktörlerin analizi. Journal of Accounting, Finance and Auditing Studies, 1(2), 78102.

Yörükoğlu, A. (2007). Davranışsal finans. Marmara üniversitesi bankacılık ve sigortacılık enstitüsü sermaye piyasası ve borsa ana bilim dalı yüksek lisans tezi, İstanbul. 


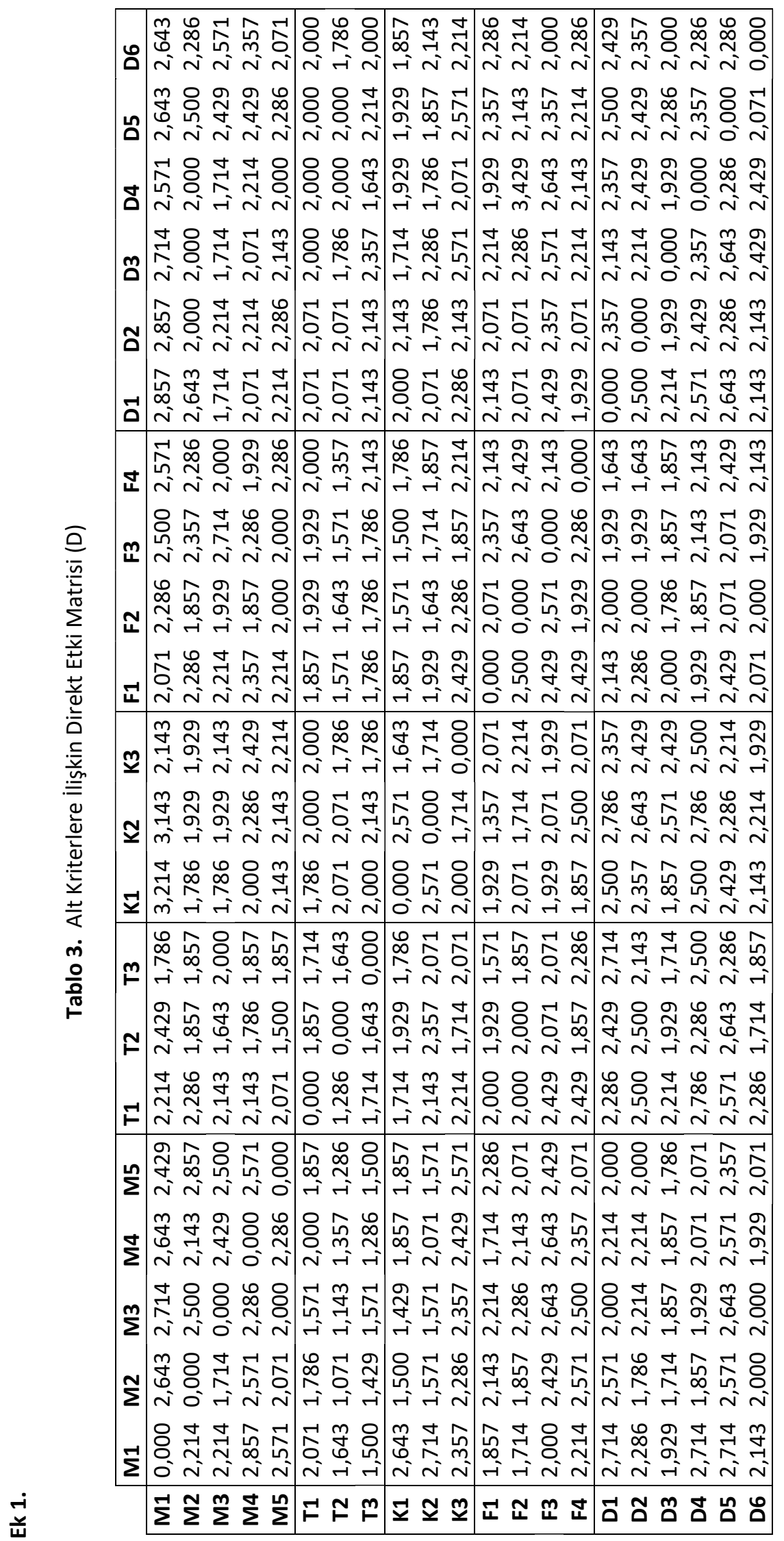




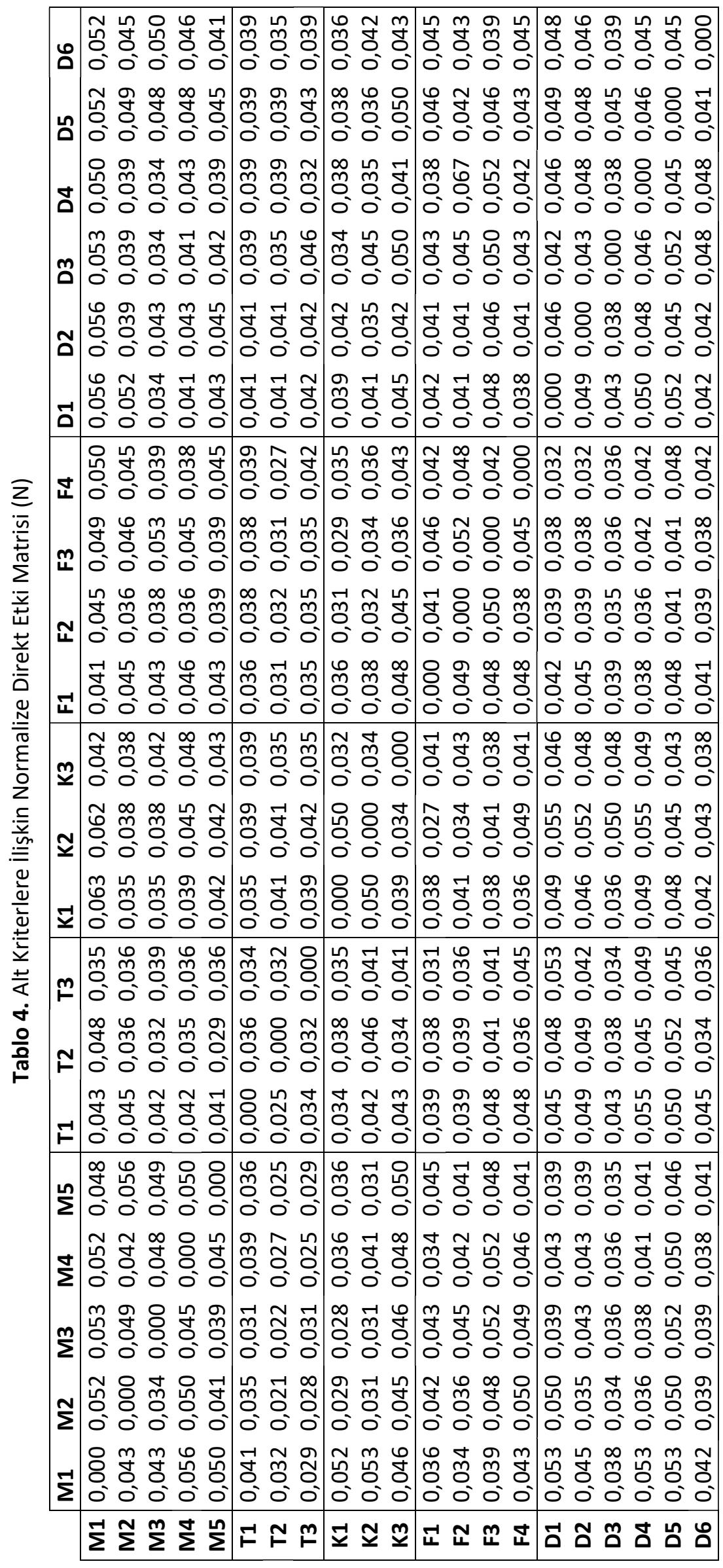


舟

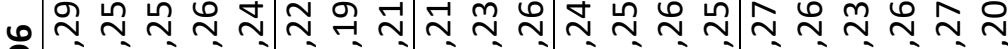

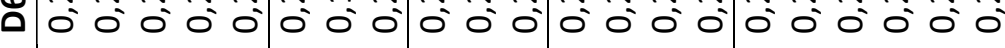
\% L m - N N N N N N

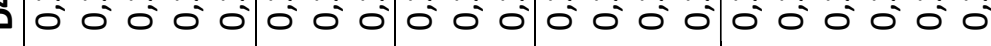
苍芯 导 מ厶 ด ᄂ พ

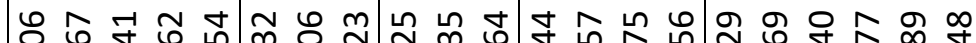
$-1 m^{-N}$ N

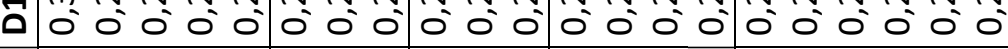

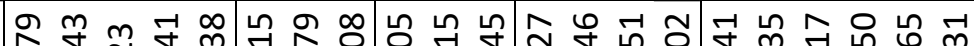

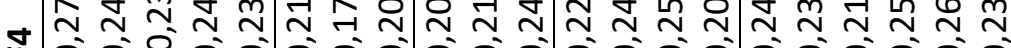

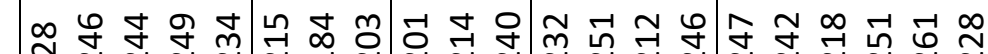
$m$ m 过

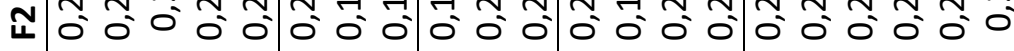

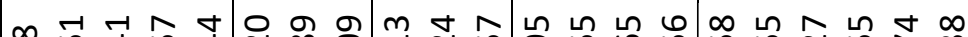
-

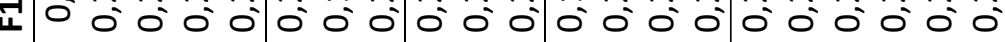
స

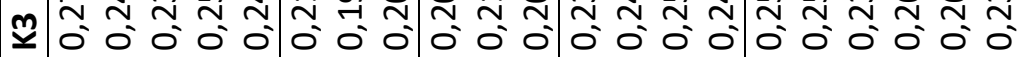

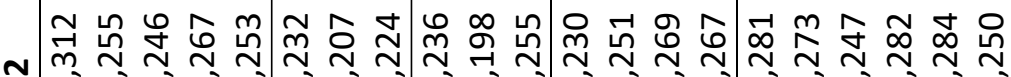

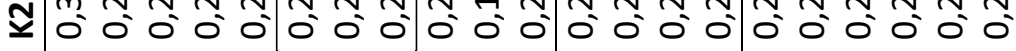

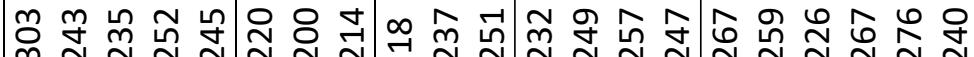
I

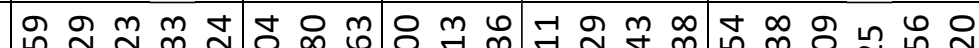

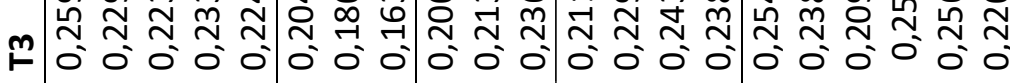

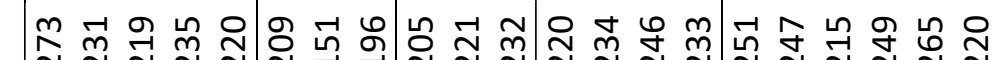

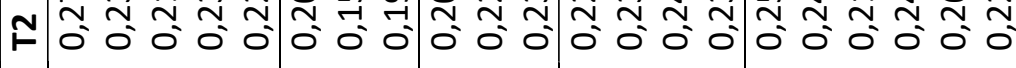

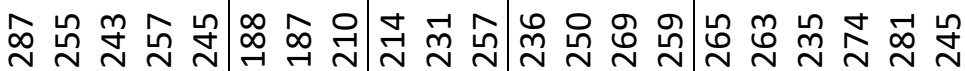

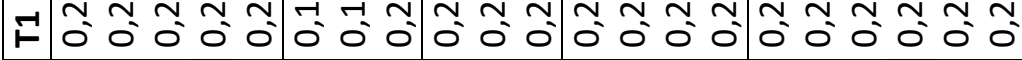
m

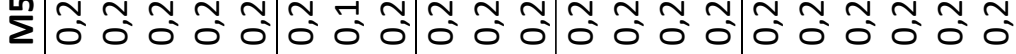

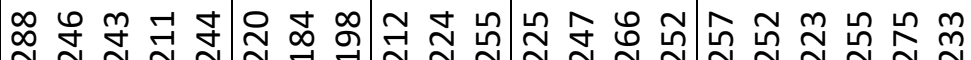

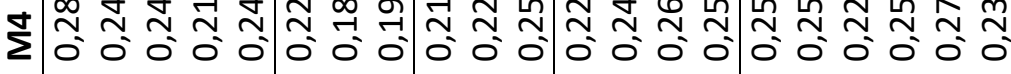
낭

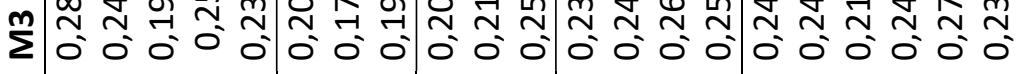

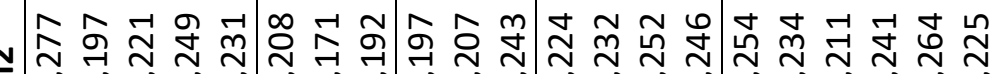

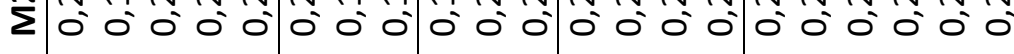
뉸

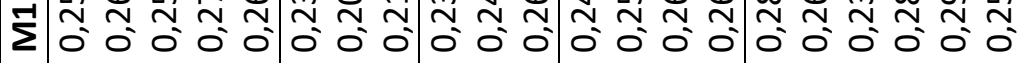

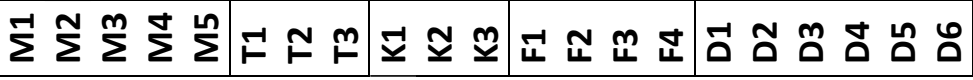


๒

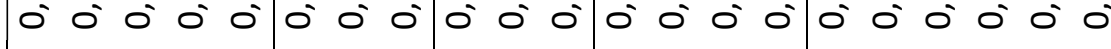

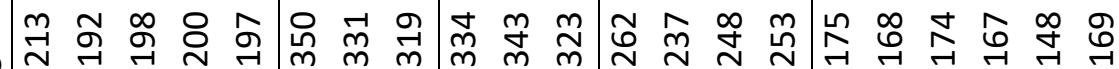

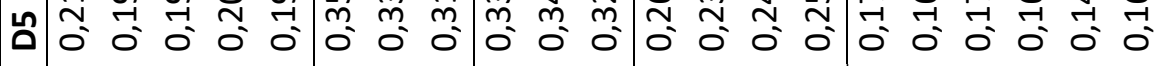
옹

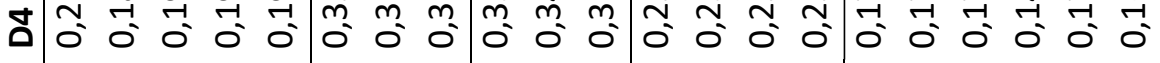
m

m

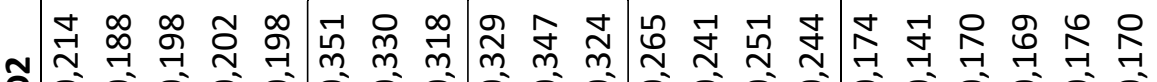

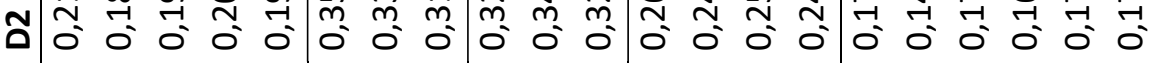
స్ㄱㅇㄱㄱ

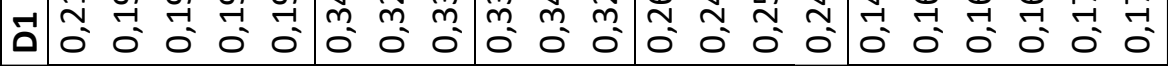

જે

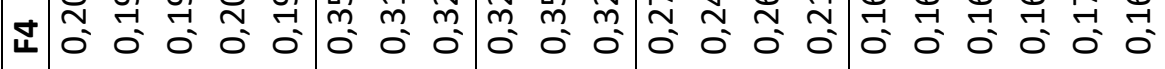

ミ

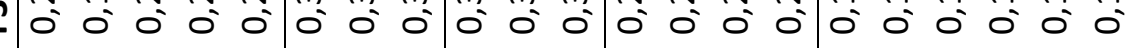

î

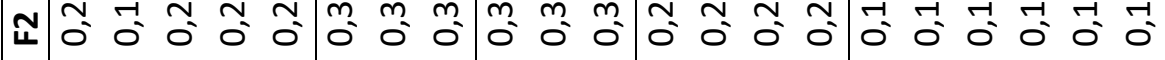

赵

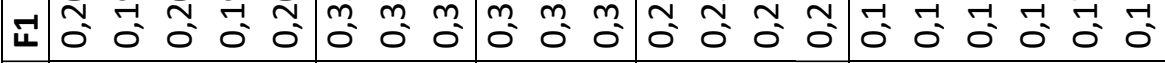

穴 ન్ન

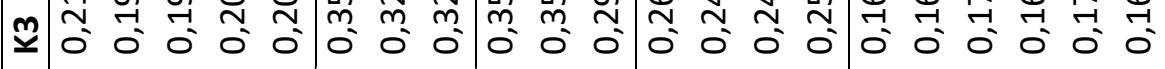

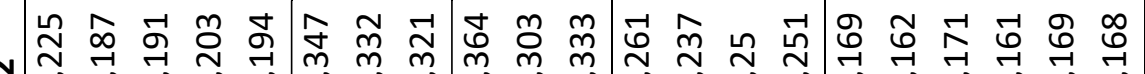

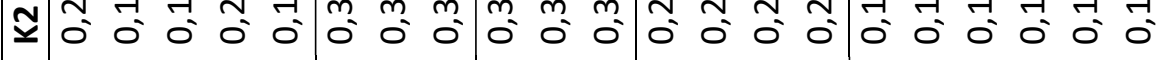

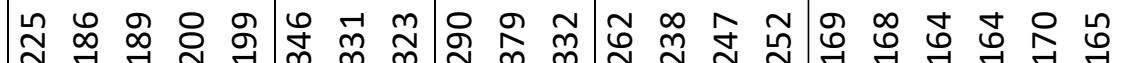

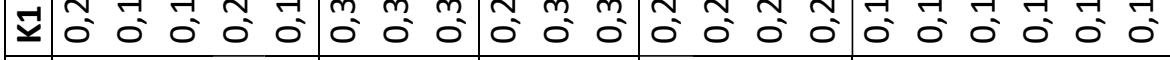

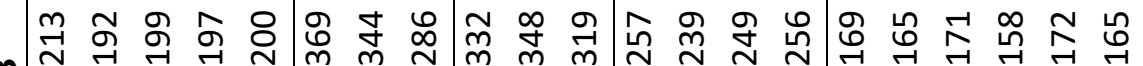

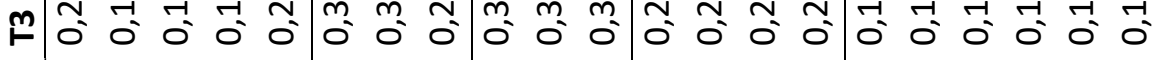

ન્ન

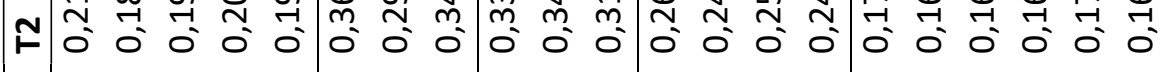

望

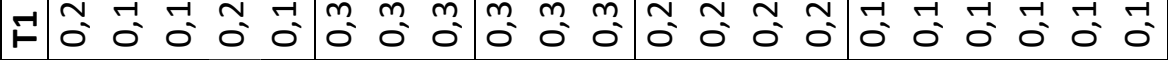

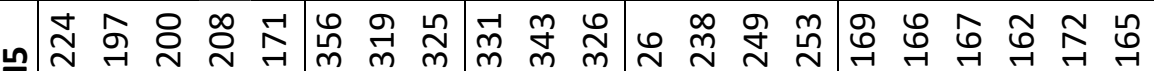

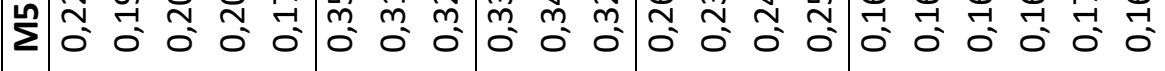

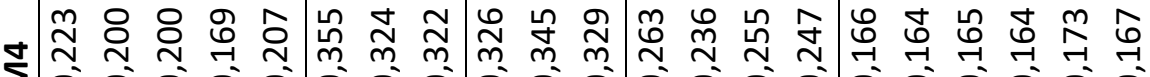

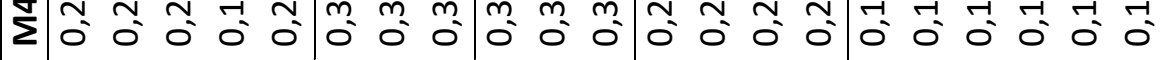

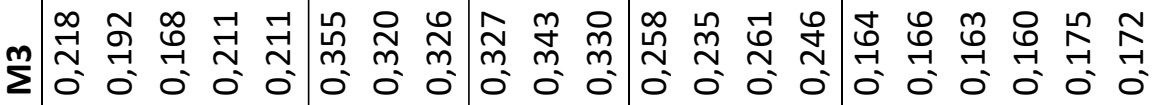

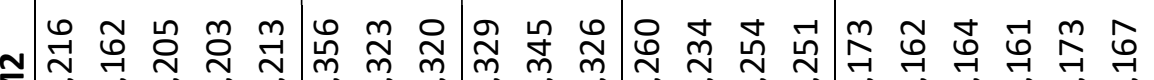

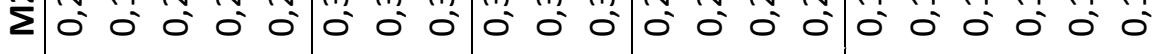

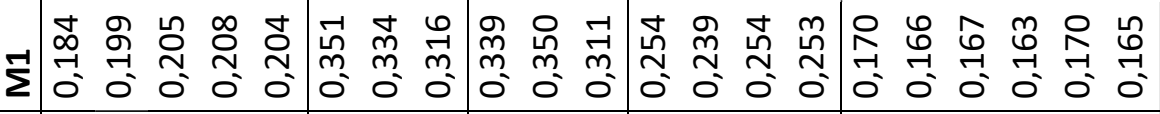

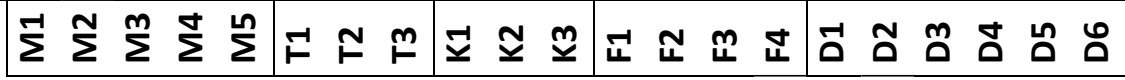




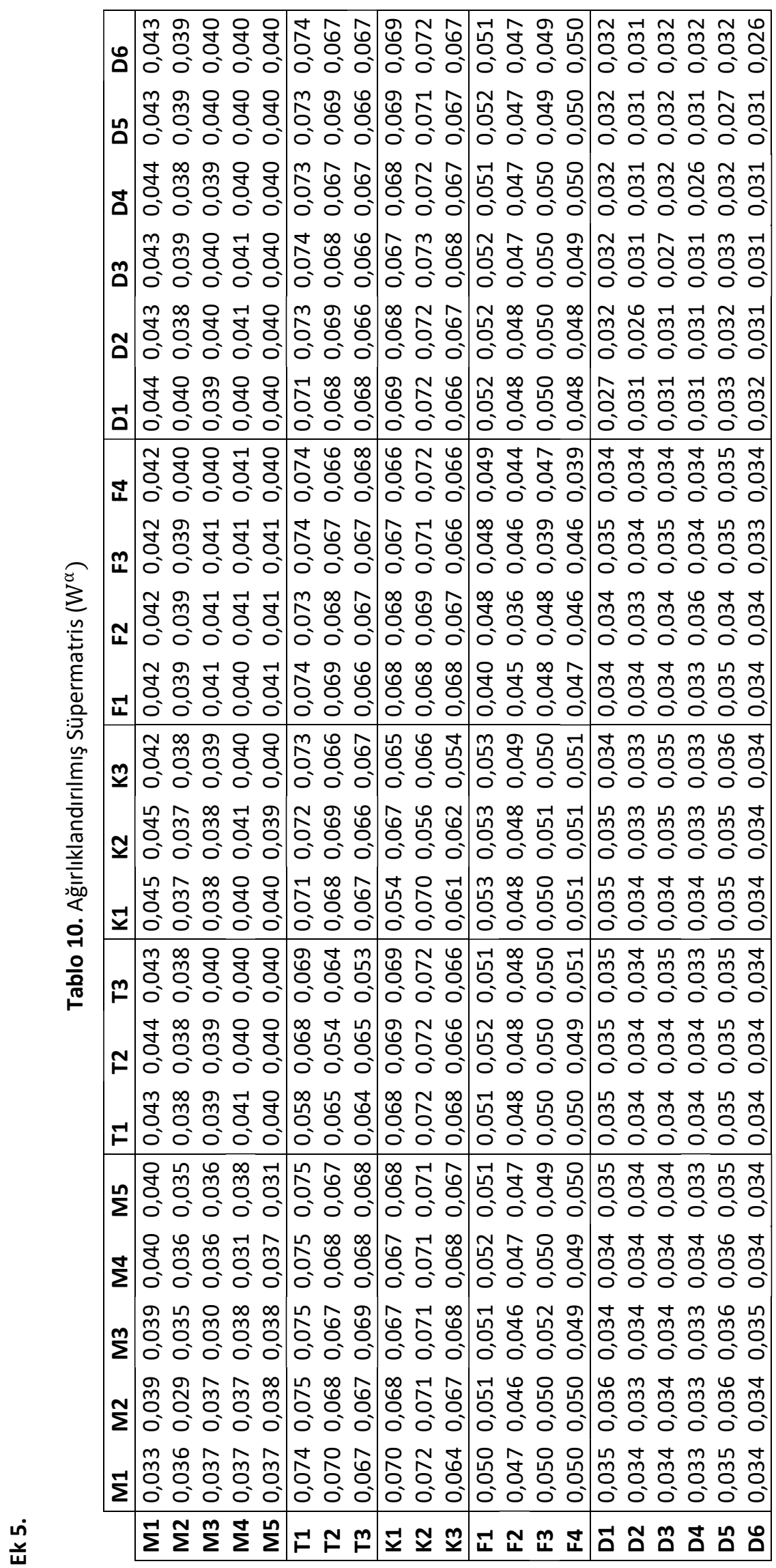




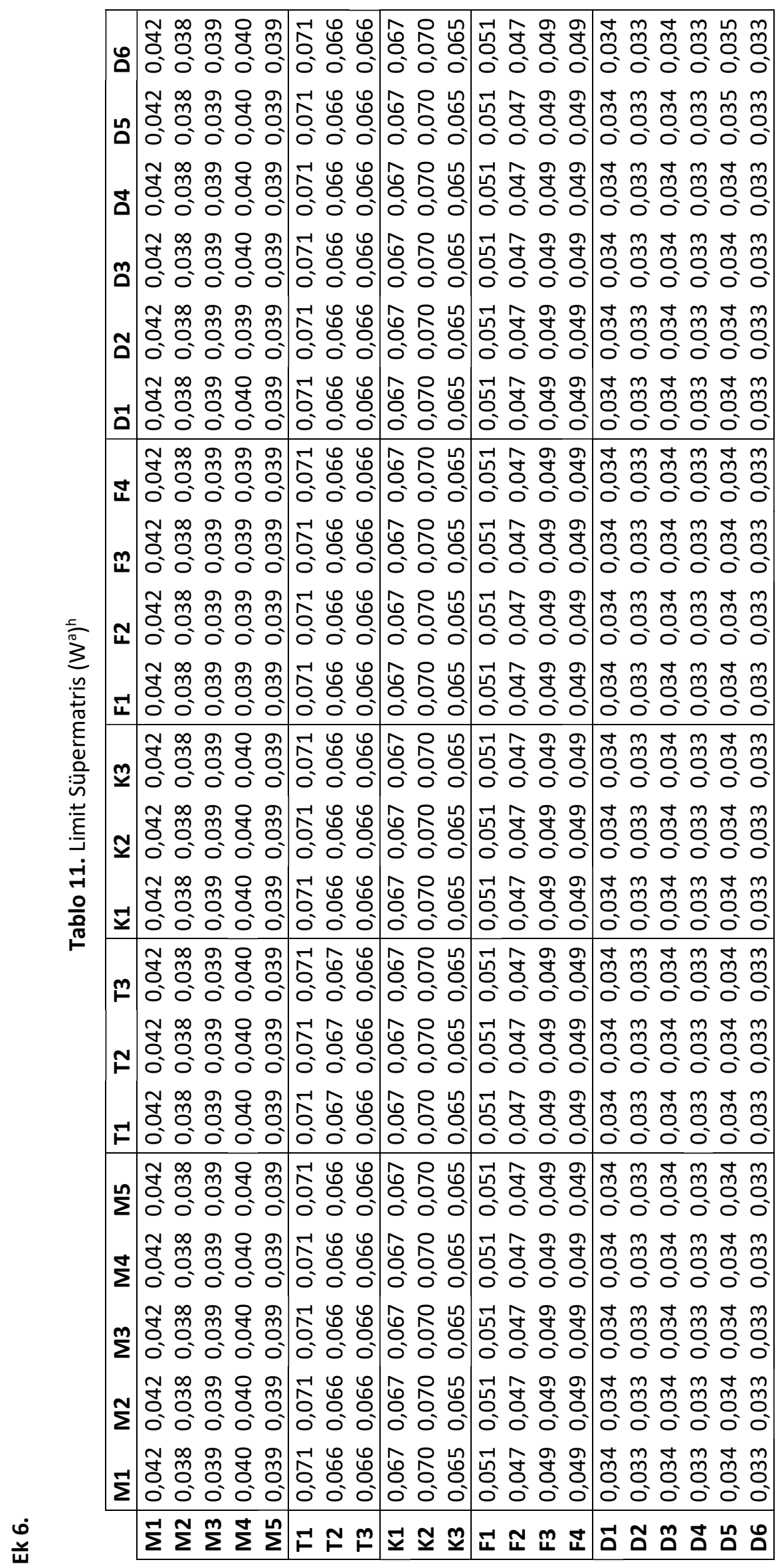

